\title{
UNIVERSITY EDUCATION IN CENTRAL AFRICA
}

T HE events which led up to the granting of a Royal Charter to the University College of Rhodesia and Nyasaland on February 11, 1955, have been reviewed in Nature $(172,1 ; 1953.173,107$; 1954. 175, 181; 1955). Now, five years after its establishment, the first results of degree examinations in the College have been announced, and it is opportune to review the five years of life of this flourishing multi-racial establishment. A basic principle in the foundation and planning of the University College was that there should be no discrimination in it on racial grounds, and, as was said in 1955 (Nature, 175, 181 ; 1955), "In a country where racial tension can arise, the position of a multi-racial University is especially important". The agreement of Her Majesty Queen Elizabeth the Queen Mother to become the first President of the College, and her presence at Salisbury when she was formally installed on July 5, 1957, were particularly happy auguries for the development of this young university institution. As President of the College she will preside at the degree ceremony on May 13, 1960, in Salisbury.

The first academic session opened in March 1957 with a total of 74 students, 8 of whom were African (Nature, 179, 612; 1957). During the session that has just closed there were 168 students, of whom 38 were African. The proportion of African students in the College is steadily rising, and, with the development of sixth-form school education throughout the Federation of Rhodesia and Nyasaland, may be expected to rise still further.

The University College is in special relationship with the University of London and the students therefore now take the degree examinations of that University. At the end of the session which has just closed 19 candidates sat for the B.A. General degree, of whom 17 were successful, one being placed in the first division. Six candidates out of the seven who sat for the B.Sc. General examination, and both of two candidates who took that for B.Sc. Agriculture, were successful in obtaining degrees. In addition, 23 out of 26 candidates successfully completed the course and examination for the postgraduate certificate in education. Of the total number of successful candidates, nine were African.

The examination results to date are a useful index of the soundness of the academic progress of the College. Nevertheless, the needed growth in breadth and depth of educational facilities still depends upon financial encouragement, and it is with great satisfaction that the news has recently been received of an offer of a grant of $\$ 250,000$ by the Nuffield Foundation towards the establishment of a Medical School at the College. Training in medicine is extremely expensive, and it was natural that the institution of a Medical School should be delayed until a number of other faculties had been established, although this ultimate development was contemplated from the start.

The generous offer from the Nuffield Foundation is made on the understanding that the teaching hospital for the Medical School takes the form of a new multi-racial hospital on the site of the University College. The University of Birmingham and the University College of Rhodesia and Nyasaland have agreed that when a Medical School is established at Salisbury it shall initially be an affiliated institution of the University of Birmingham. This means that, for the period of affiliation, the students of the Medical School of the University College will be prepared for the degrees in medicine of the University of Birmingham just as those in the Faculties of Arts and Science at present prepare for the degrees of the University of London.

As so often seems to hold for university institutions, the financial support of the University College is scarcely adequate for all that, on other grounds, it might hope to do. Her Majesty's Government, which in the past has provided capital money totalling $£ 1,475,000$, has recently made a further generous grant of $£ 1,400,000$ towards capital costs for the College. The Government of the Federation of Rhodesia and Nyasaland has provided $£ 750,000$ over the first five years, for recurrent expenditure, and one may hope that it will give further generous support during the new quinquennium to help to provide for the cost of the much needed expansion which is already planned. At present, besides medicine, the College lacks only engineering and theology among the major faculties to be expected in a university institution.

The working out of a plan for racial partnership in all its details vitally depends upon the co-operation of educated people of all kinds. The significance of education, and particularly the higher education of Africans, in the working out of such a plan must be clear to all.
F. G. YounG

\section{ADMINISTRATION OF UNIVERSITIES}

$\mathrm{T}$ HE chuckles in academic circles when Prof. C. Northcote Parkinson presented his famous law to explain certain empire-building propensities of industrial leaders may now be echoed by chortles from industrial leaders who read an article by Parkinson which deals with related matters in universities (The Universities Review, 32, No. 1; October 1959).

Although British universities do not yet boast the organizational luxuriance of American universities- the University of Pittsburg has a chancellor, three vice-chancellors, three assistant chancellors and sixteen directors, eighteen deans and a host of other executives-Parkinson asks whether British universities are not proceeding in the same direction.

A recent study of the expenditure of some fifteen British universities shows that the percentage of their allocation to 'administration' varies between 5 and 10.6 per cent of their annual budget, Bristol spending the least and Exeter bracketed with 
Leicester in spending the most. The average is about 7.2 per cent-a not manifestly exorbitant proportion. Expenditure between universities is not an easy comparison to make, for much depends upon the detailed layout of the estimates. Nevertheless, the universities which spend more than 10 per cent might learn something from those which spend only 5 per cent. What these figures do not reveal is the extent to which academic time and effort are diverted to administration on a part-time basis. This is a field in which statistical comparison is more difficult. All that is gathered is a vague impression of middleaged scholars bewailing the administrative work thrust upon them; a complaint sometimes intended to excuse their lack of literary or scientific output. Eagerness for office is due to several causes, among which the most important is the least noticed. Presiding over a committee or dictating a routine correspondence is far easier than doing a good piece of research. It may often be better paid and frequently leads to the higher offices and honours, so that the scholar is offered every inducement to desert the library and take to the filing cabinets. Part of the trouble with British university administration centres on this inducement. For those most easily tempted along the easier path are not necessarily the most competent, though many of them prove to be so. In some instances, the burdens of which they complain have become burdensome as a direct result of their own inefficiency.

Those who admire the system of some larger American universities would wish to give more extensive powers to the executive head. There is no assurance, however, that this would be either an improvement or an economy. What is needed is an equivalent of the army 'p.s.c.', a higher qualification to be obtained by a short course and accompanied by an impartial and secret assessment. "Could not some university organize a staff course in higher administration, to be supervised by retired vicechancellors and held at some centre for research which could be furnished with all the information available about all the universities of the world?" The course would be held in the vacation and designed for those who had been in charge of departments and for whom higher responsibilities might be predicted. After some experience of the course, universities might limit their higher offices to those who had gained this qualification.

For a scheme of this sort one strong argument from army experience is worth noting. Such faults as were apparent in the British generals of the Second World War were seldom or never attributed to lack of brains. There were failures in leadership ; but the staff college system prevented any repetition of Balaclava. The same cannot be said of the university world. Such a staff college would provide a readymade group of advisers to which a university might turn for guidance.

There are some arguments on the other side. Some of these will derive from that strange reluctance which academic persons reveal when invited to apply scientific method to university affairs. There is no insoluble problem in academic administration so long as the university is kept down to a reasonable size. But there are problems which remain unsolved merely because those immediately concerned lack the ability to find a solution and because they fail to apply the sort of method which they would apply without hesitation to matters more obviously scientific. In this matter of using a methodical approach to a political problem, the universities have not only a duty to themselves but also a further duty, by way of example, to the world.

\section{THE NUFFIELD FOUNDATION}

$\mathrm{T}$ HE fourteenth annual report of the Nuffield Foundation (pp. xii +201 . London: The Nuffield Foundation, 1959), covering the year ended March 31,1959 , records for the first time expenditure on grants exceeding $£ 1$ million, and of this $£ 1,137,900$, roughly a quarter was spent in the Commonwealth, mostly in Africa, and the rest at home on scientific, medical and social projects and on fellowships. With regard to the last it may be noted that since 1946, 357 travelling fellowships have been awarded, and from the beginning the Foundation has made a special point of enabling the married overseas fellow to be accompanied by his wife and for its married Fellows has provided a small colony of furnished flats in Prince Albert Road, London. Travel grants during the year have covered the visit to England of Mr. R. C. Robinson, a neurosurgeon from the University of Otago Medical School; a visit to Dr. D. G. Abraham, Ibadan, by Dr. Wallace Brigden to study a puzzling heart condition; a lecture tour in Canada by Sir Christopher Ingold, arranged by the Chemical Institute of Canada; and a study visit on Commonwealth constitutional law by Prof. C. H. Alexandrowicz, of the University of Madras. Three medical fellowships, three fellowships and four scholarships in dentistry were awarded during the year, but the scheme for sociological scholarships and bursaries was diseontinued and a new scheme of senior sociological scholarships initiated experimentally for three years. Only one travelling fellowship for Home Civil servants was awarded, but eight travelling fellowships were awarded in medicine, twelve in natural science, and nine in humanities and social science, while twenty. three awards were made under the Royal SocietyNuffield Foundation Commonwealth bursaries seheme.

In this report the Foundation, welcoming the new emphasis placed by the Government on the teaching of technology, records that, after considering how best it could help without trespassing on public responsibilities, the Foundation has decided that its chief interest should be in the technological colleges providing advanced courses. Thəse colleges have a different purpose from the technological departments of universities, deriving from the belief that some students mature better if their theoretical training is more closely interwoven with industrial practice than is usual or desirable for university students. It considers that all such colleges need to establish a fruitful partnership with the industries with which they are most intimately associated, and while refraining from adopting a detailed programme of schemes for sandwich courses, for example, for which it would be willing to provide grant-aid, has indicated its interest in experimental schemes designed to achieve closer unity between the colleges and industry and in schemes which would benefit technological industry 